\title{
ANALYSIS OF CURRENT STATE AND LIMITING FACTORS FOR THE DEVELOPMENT OF ORGANIC SECTOR IN SERBIA ${ }^{1}$
}

\section{Vlado Kovačević ${ }^{2}$}

\begin{abstract}
The aim of this paper is to analyse the current situation and potential for the development of organic agriculture in Serbia. Despite the favourable agri-ecological conditions for the development of organic agriculture, this branch of agriculture in Serbia significantly lags behind the world and European average in terms of the percentage of agricultural land under organic production. The motive for the conducted analysis within this paper stems from the fact that the demand for organic products in the EU has been increasing at a rate of about $10 \%$ annually in recent years, which represents a chance for Serbian agriculture. Data sources used are from the Ministry of Agriculture, Forestry and Water Management of the Republic of Serbia (MAFWM), Statistical Office of the Republic of Serbia (SORS) and Research Institute of Organic Agriculture (FIBL) while the basic research method is interview with experts and participants in organic agriculture. The results of the analysis show that the main limiting factors for the development of Serbian organic agriculture are dominance of small and economically weak producers and insufficient consumer confidence in organic products. The path to the development of organic agriculture is in the increased cooperatives activity and the improvement of consumer confidence in organic products.
\end{abstract}

Key words: foodstuff quality schemes, organic agriculture, supply chain.

JEL³: O38, I25

\section{Introduction}

Organic agriculture has been defined as production focused on reduced input use and the preservation of ecosystem functions. Growing populations in recent decades posing challenge to agriculture toward intensification natural resources use (Godfray et al., 2010; Mie et al., 2017; Seufert et al., 2017). Opposite process is in

1 Paper is a part of research financed by the Ministry of Education, Science and Technological Development of the Republic of Serbia (MESTD) agreed in decision no. 451-03-9/2021-14 signed between the IAE Belgrade and MESTD.

2 Vlado Kovačević, Ph.D., Senior Research Associate, Institute of Agricultural Economics, Volgina Street no. 15, 11060 Belgrade, Serbia, Phone: +381 63554 414, E-mail: vlado_k@,iep.bg.ac.rs

3 Article info: Original Article, Received: 13 ${ }^{\text {th }}$ January 2021., Accepted: $25^{\text {th }}$ February 2021. 
the developed countries where is demand for production of healthy foodstuff with limited use of inputs in agriculture production (Macdiarmid et al., 2011; Kljajić et al., 2013; Sredojević et al., 2015).

Agricultural sector is contributing with $7 \%$ of Serbian GDP, accounting in total national employment with $16 \%$. Agriculture is rare Serbian economy sector with constant foreign trade surplus and with contribution of $18 \%$ in export in 2019 (MAFWM, 2020a).

Figure 1. Organic production area (share in total agricultural land in Europe, in 2018.)

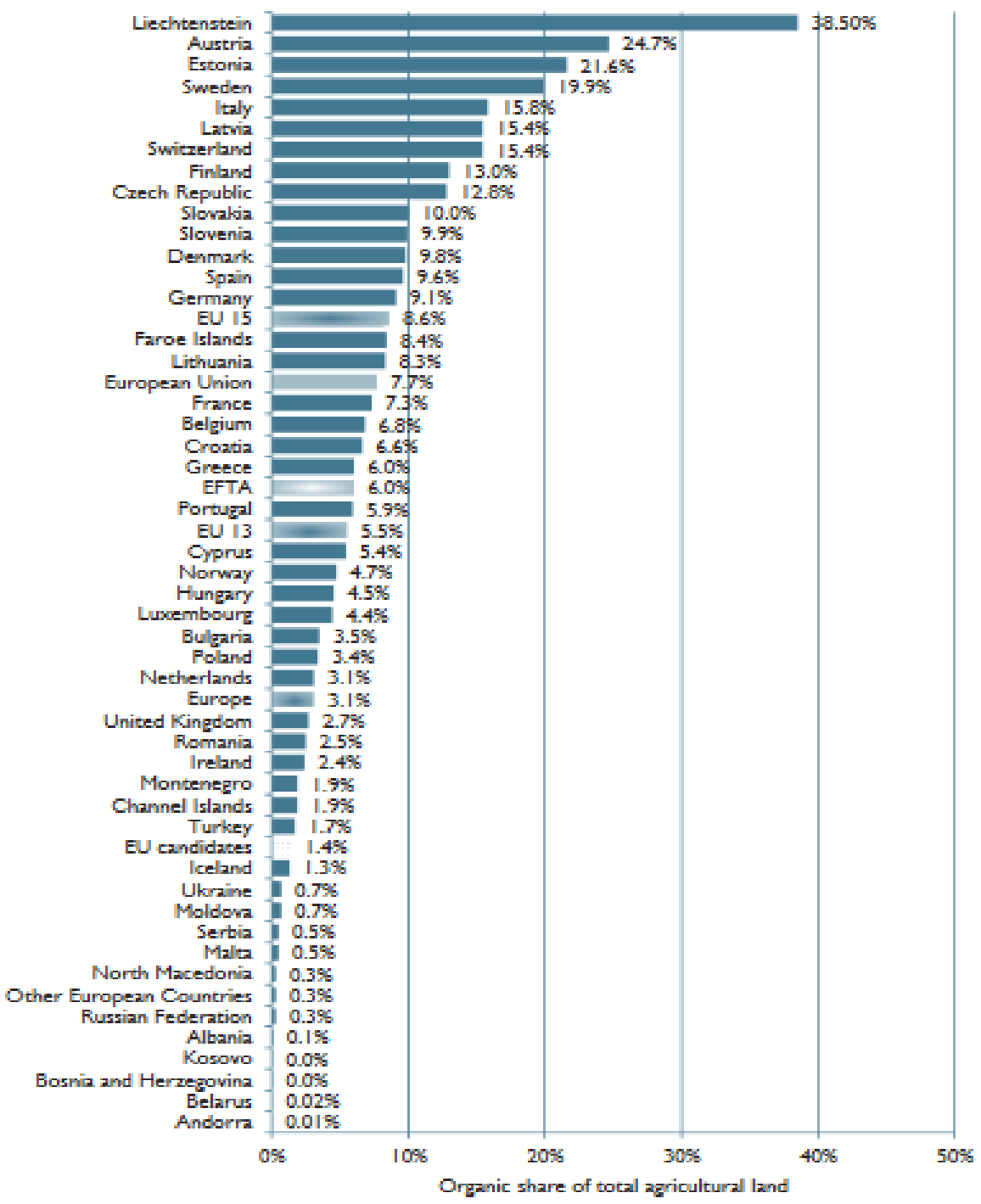

Source: Willer et al., 2020. 
Important fact is that small farms with estate in average of 5.4 ha and that are lacking in economic power are dominating in Serbia (SORS, 2012). Small farms path to the competitiveness should be found in added value products such as organic production. It is a disadvantage for organic agriculture but in conventional agriculture it will be even bigger disadvantage, that why small farms better fit in added value production as organic. Despite to the above-mentioned conditions, Serbia is lagging behind World and EU average area under organic production (Figure 1.).

Of importance for organic agriculture in Serbia are the two newly adopted EU Strategies: Farm to Fork Strategy for a fair, healthy and environmentally-friendly food system (EC, 2020b) and the Strategy for Biodiversity Protection until 2030. (EU Biodiversity Strategy for 2030 - Bringing nature back into our lives), (EC, $2020 \mathrm{a})$. The EU plans to ensure that at least $25 \%$ of agricultural land is certified as organic instead of the current $8 \%$. The development of the organic sector and the achievement of the planned EU goals in organic agriculture will positively impact the process of Serbia's accession to the EU.

Organic agriculture in Serbia is growing, in farmland and volume of production in slow pace. Organic products are the mostly marketed in large cities due to the higher users' purchasing power and the high informational level (Paraušić, Roljević Nikolic, 2020). Organic production in Serbia is regulated by the Law on Organic Production (OGRS, 30/2010 and 17/2019).

The main paper goal considers analysing of the current situation and available potentials for the development of organic agriculture in Serbia.

\section{Methodological Framework}

To provide objective results, the following methods were used in paper development:

- Intensive literature review;

- Semi-structured interview of 7 retail chains (total number of retail chains is 9) conducted by the author on behalf of Deutsche Gesellschaft für Internationale Zusammenarbeit GmbH (GIZ). Survey is conducted in the period June November 2020 (Serbia Organika, 2021);

- Comparative analyses;

- Consultations with stakeholders in organic agriculture sector;

- Graphical presentations.

Used data sources in paper development consider MAFWM, SORS and FIBL. 


\section{Results and Discussion}

In this part of the paper main obstacles for faster development of the organic agriculture in Serbia are analysed, followed with recommendation for improvements. The analyse is conducted based on extensive literature review, consultations with relevant experts in foodstuff supply chain and organic agriculture, as well as organic farmers, organic foodstuff processors, certification bodies and agrarian policy makers. Research covers the period 2010-2020.

Slow progress in area under organic production is notable, mostly caused by the undeveloped market, low agricultural cooperatives activities, lack of institutional settings, etc. (Figure 2).

Figure 2. Areas under organic production (in ha, period 2010-2019.)

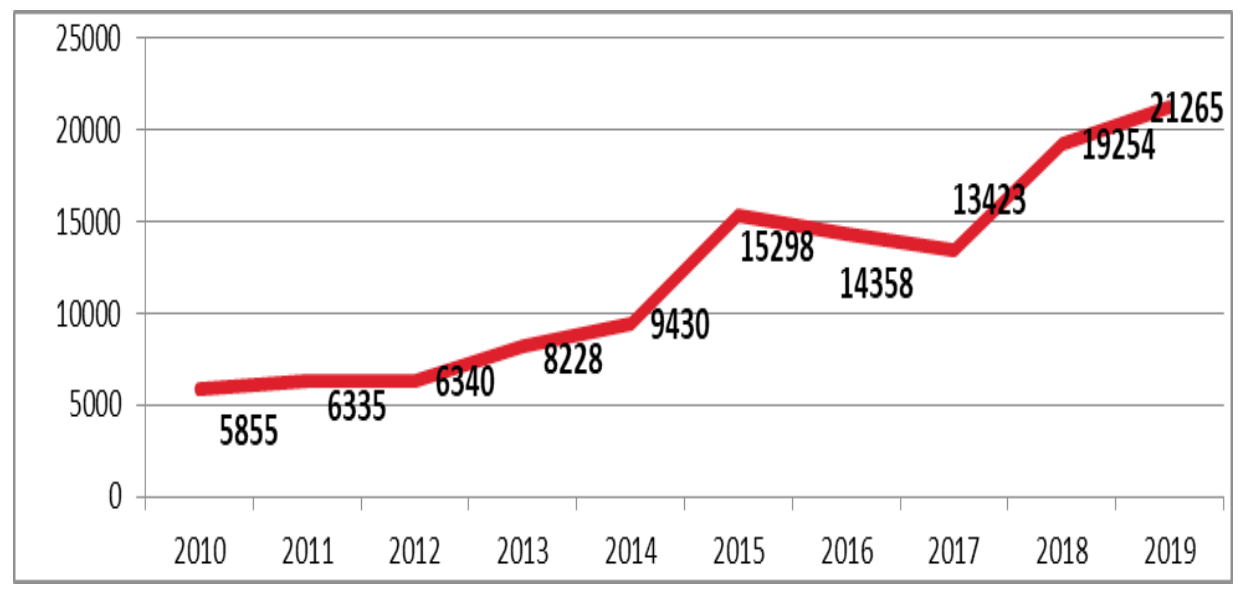

Source: MAFWM, 2020b.

Serbian organic agriculture is increasing but legging significantly behind the European rate of increase (Willer et al., 2020).

Organic production in Serbia in 2019. took place on a total area of 21,265 ha, which is $10.44 \%$ more than the area in 2018 . Of that, arable land amounted to 15,915 ha, including meadows and pastures on the area of 5,350 ha (Table 1.). 


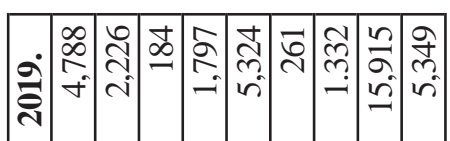

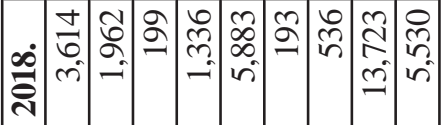

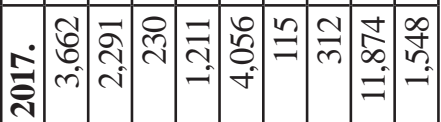

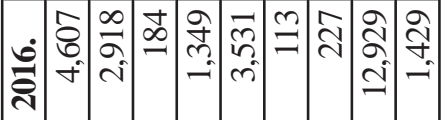

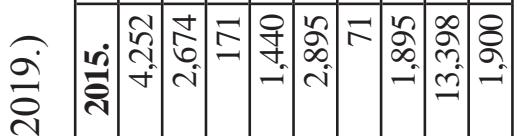

ஸ்

ซु ฟิ กิ

·

ปี่

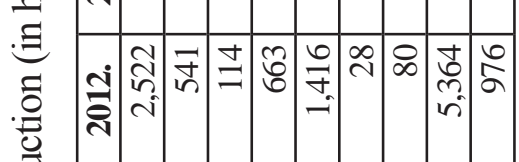

בृ้

능

究

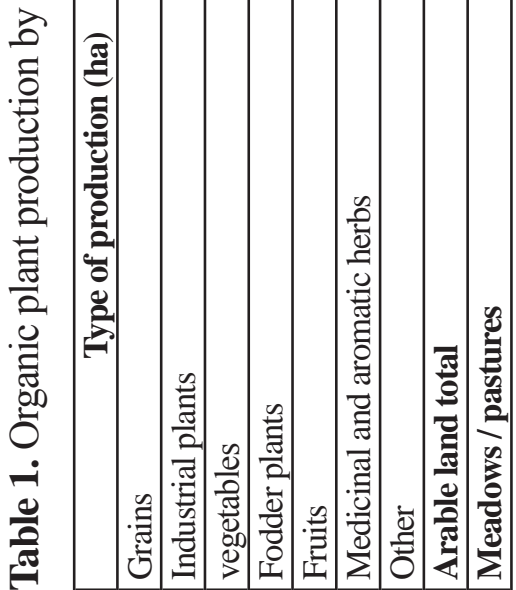

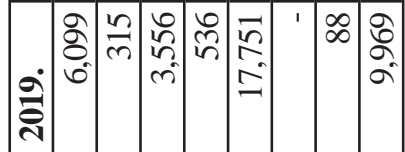

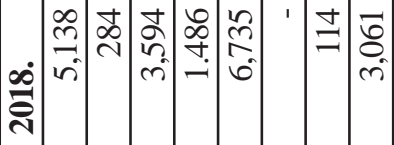

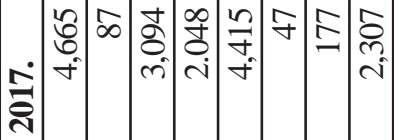

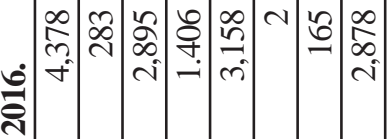
ลี่

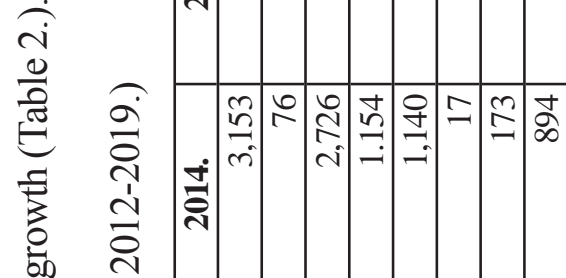

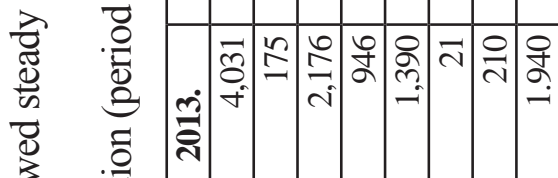

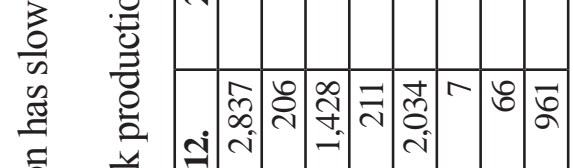

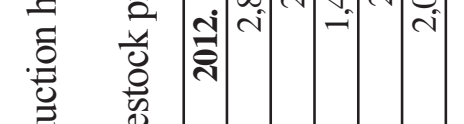

ते के है

ते

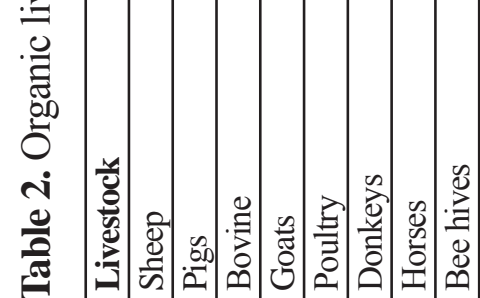

¿ิं 
During 2019., the number of producers involved in organic production increased from 500 in 2018. to 534 certificate holders, while the number of certified individual farmers decreased from 6,206 in 2018. to 5,727 in 2019. (Table 3.). Serbia has allowed group organic certification which is widespread practice in organic agriculture (Grujic Vuckovski, Kovacevic, 2020). Group organic certification is certification system where certificate holder organises group of farmers to be certified as a one entity. Advantage of this kind of certification is primarily in its lower certification costs.

Table 3. Number of producers involved in organic production in Serbia (period 2012-2019.)

\begin{tabular}{|l|r|r|r|r|r|r|r|r|}
\hline \multicolumn{1}{|c|}{ Year } & \multicolumn{1}{|c|}{$\mathbf{2 0 1 2}$} & \multicolumn{1}{c|}{$\mathbf{2 0 1 3}$} & $\mathbf{2 0 1 4}$ & $\mathbf{2 0 1 5}$ & \multicolumn{1}{c|}{$\mathbf{2 0 1 6}$} & $\mathbf{2 0 1 7}$ & $\mathbf{2 0 1 8}$ & \multicolumn{1}{c|}{$\mathbf{2 0 1 9}$} \\
\hline $\begin{array}{l}\text { Number of certificate } \\
\text { holders }\end{array}$ & 237 & 258 & 291 & 334 & 390 & 434 & 500 & 534 \\
\hline $\begin{array}{l}\text { Number of certified } \\
\text { individual farmers }\end{array}$ & 836 & 970 & 1,575 & 1,955 & 2,404 & 5,719 & 6,206 & 5,727 \\
\hline
\end{tabular}

Source: MAFWM, 2020b.

Table 4. provides the assessment of core elements of marketing of organic products in retail chains.

Table 4. Assessment of core elements of marketing of organic products in retail chains

\begin{tabular}{|l|c|}
\hline \multicolumn{1}{|c|}{ Core elements } & Rate* \\
\hline Organic product quantity & 5 \\
\hline Price & 2 \\
\hline Minimum quantity & 1 \\
\hline Payment period & 3 \\
\hline Risk & 3 \\
\hline Delivery continuity & 1 \\
\hline Packaging and labelling & 1 \\
\hline Delivery conditions & 1 \\
\hline Unsold product return policy & 1 \\
\hline
\end{tabular}

Source: Serbia Organika, 2021.

*The elements are graded from 1-5, where 5 represents the most favourable scenario for the supplier while 1 represents the least favourable scenario.

Based on results shown in Table 4., the most significant advantage of placing organic products within retail chains is the ability to market large quantities or products, while, given the very high criteria in terms of packaging, supply and delivery continuity, etc. These are also the most demanding marketing channels (Serbia Organika, 2021). 
Retail chains are the most important foodstuff supply chains (Astill et al., 2019). Based on the analysis of retail chains for organic foodstuff, it is clear that the most important supply chain for organic agriculture is not available for most organic producers in Serbia. Although according to research, small producers are in retail chains, they have poorer marketing results, i.e. higher transport prices, considering that they deliver smaller quantities of products, lower bargaining power, lower price, worse other sales conditions, etc. All of the above indicates that small producers need to team up to achieve lower marketing costs and better sales conditions in retail chains. In a longer period of time, small organic producers will disappear from retail chain supply channels (Serbia Organika, 2021).

According to analyses main factors limiting development of the organic agriculture are:

1) Lack of Marketing information system for organic products. Price reports on conventional agricultural products are included within the Marketing informational system (STIPS), governing by the MAFWM (STIPS, 2021).

Recommendations: to include price reports on organic agricultural products at the STIPS.

2) According to the results of the conducted analyses, the main reason for the lag of Serbian organic agriculture lies in the poorly developed domestic market of organic products. The most significant obstacle to further improving the trade of organic products is the lack of consumer confidence that the organic product is produced in accordance with the basic principles set out in the law.

Recommendations: improvement of records of organic production, which would reduce the possibility of negligent behaviour and improvement of control of organic products through systematic sampling of products at retail outlets. Increase in the consumer confidence in organic products, will lead to increase in demand, thus increasing production, which will lead to improved economic effects and, on the other hand, that will provide larger areas under organic crops and positively impact the environment.

3) The results of the analysis show that the degree of association of organic producers of small and economically weak farms is very low. Associated small organic producers have lower costs of group certification, procure more favourable inputs, significantly improve product placement, have access to new technologies and knowledge, and can establish joint processing, packaging, and storage of organic products. The number of cooperatives and theirs activities in Serbia are tens of times smaller than in the EU, the same applies to the size of assets owned by cooperatives (Milovanovic, Kovacevic, 2017). 
Recommendations: According to the research results, the system of interest associations should be developed through three segments: 1) Amendment to the Law on Cooperatives (OGRS, 112/2015). Based on the conducted analyses, the main areas of improvement of the Law on Cooperatives are: enabling organic producers/processors that are legal entities to be members of cooperatives (practice in almost all EU countries that legal entities can be members of cooperatives). Regulation of property relations, in cooperatives currently the cooperative share owned by a member of the cooperative in case of his leaving the cooperative cannot be sold to another member of the cooperative but the cooperative must pay the value of the cooperative share to the cooperative. Payment of the cooperative share is the obligation of the cooperative, which may unnecessarily be a financial burden for the cooperative, secondly, the cooperative member can wait several years for payment, thirdly, the question arises as to the value of the cooperative pays the cooperative share, namely nominal (book value) greater than real market value. If the turnover of cooperative shares between the members of the cooperative were enabled, the payment of the same would not be a burden on the account of the cooperative, the cooperative share would be traded at market value, etc.; 2) Establishment of a stimulating business environment for interest associations of organic and other producers. In Serbia, a stimulating environment for the operation of cooperatives has not been established. There are ad hoc measures, while systemic support measures have not been established as preferential tax treatment for cooperatives or other long-term structural measures. As a positive example, it could be taken the EU practice in Italy and other members where cooperatives that in the previous accounting period achieved the volume of business with their members over $50 \%$ receive tax relief, only cooperatives that had the appropriate volume of business in the previous accounting period are entitled to subsidies with its members. Improving the business environment would significantly improve the work of cooperatives of organic producers and the placement of organic products; 3) Establishing legal preconditions for the establishment of producer organizations and producer groups; 4) Introduction of far and transparent process of land restitutions, which will affect increased area under organic production as well (Rajnović et al., 2020).

4) It is of importance to enable small organic producers to process organic products on their farms. The Rulebook on the production and trade of small quantities of food of plant origin, the area for performing these activities, as well as the exclusion, adjustment or deviation from the requirements of food hygiene (OGRS, 13/2020) force farms to register the processing under simplified conditions as a physical person. The obstacle in the realization of the mentioned 
benefits is the obligation to register in the Central Register of Facilities kept in the MAFWM, which is allowed only to legal entities, so that organic producers who are in the status of agricultural holding cannot use the mentioned benefit.

Recommendation: The necessary change within the Central Register of Facilities kept in the MAFWM, which will allow enrolment of the individual farmers.

\section{Conclusion}

Despite the excellent conditions, Serbian organic agriculture remains significantly behind the world and EU average. Added value products such as organic products are pathway toward competitive and sustainable agriculture due to small farm size and poor economic power this farm cannot compete with high yields of average quality products. It is noticeable that Serbian agriculture is developing with slow peace in recent years, caused by 1) Lack of Marketing information system for organic products. Price reports on conventional agricultural products are included within the Marketing informational system (STIPS) governing by the MAFWM; 2) Shallow domestic market of organic products. The most significant obstacle to further improving the trade of organic products is the lack of consumer confidence that the organic product is produced in the prescribed manner; 3) Lack of cooperatives. It is the improvement of the interest association of organic agricultural producers that is the way to improve the production, processing and marketing of organic products. Associated small organic producers have lower costs of group certification, procure more favourable inputs, significantly improve product placement, have access to new technologies and knowledge, and can establish joint processing, packaging, and storage of organic products; 4) It is of importance to enable small organic producers to process organic products on their farms. The necessary change within the Central Register of Facilities kept in the MAFWM, which will allow enrolment of the individual farmers.

\section{References}

1. Astill, J., Dara, A., Campbell, M., Farber, M., Fraser, E., Sharif, S., Yada, Y. (2019). Transparency in food supply chains: A review of enabling technology solutions. Trends in Food Science \& Technology, 91:240-247, https://doi. org/10.1016/j.tifs.2019.07.024

2. EC (2020a). EU Biodiversity Strategy for 2030: Bringing nature back into our lives. Communication from the Commission to the European parliament, the Council, the European economic and social committee and the committee of the regions $\operatorname{COM}(2020), 380$ final. 
3. EC (2020b). A Farm to Fork Strategy - for a fair, healthy and environmentallyfriendly food system. Communication from the Commission to the European parliament, the Council, the European economic and social committee and the committee of the regions, $\operatorname{COM}(2020), 381$ final.

4. Godfray, H. C. J., Beddington, J. R., Crute, I. R., Haddad, D., Lawrence, D., Muir, J. F., Pretty, J., Robinson, S., Thomas, S., Toulmin, C. (2010). Food security: The challenge of feeding 9 billion people. Science, 327(5967):812-818.

5. Grujic Vuckovski, B., Kovacevic, V. (2020). Organic agricultural production as a quality standard. In: Platania, M., Jeločnik, M., Neta Gostin, I. (Eds.) Organic, farming, eco-market and their capitalization through the entrepreneurial initiative, Alexandru Ioan Cuza University Press, Iasi, Romania, Institute of Agricultural Economics, Belgrade, Serbia, pp. 103-127.

6. Kljajić, N., Mijajlović, N., Arsić, S. (2013). Organic production and its role in environmental protection. Scientific Papers Series, Management, Economic Engineering in Agriculture and Rural Development, 13(3):17-25.

7. Law on Cooperatives, Official Gazette of RS (OGRS) no. 112/2015.

8. Law on Organic Production, Official Gazette of RS (OGRS) no. 30/2010 and 17/2019 - other law.

9. Macdiarmid, J., Kyle, J., Horgan, G., Loe, J., Fyfe, C., Johnstone, A., McNeill, G. (2011). Livewell: A Balance of Healthy and Sustainable Food Choices, World Wildlife Fund (WWF) UK, Surrey, UK.

10. MAFWM (2020a). Green Book no. 1 for 2019. Ministry of Agriculture, Forestry and Water Management of the Republic of Serbia (MAFWM), Belgrade, Serbia.

11. MAFWM(2020b). Reporton organic agriculture for the period 2010-2019. Data received on request, Ministry of Agriculture, Forestry and Water Management of the Republic of Serbia (MAFWM), Belgrade, Serbia.

12. Mie, A., Andersen, H. R., Gunnarsson, S., Gunnarsson, S., Kahl, J. (2017). Human health implications of organic food and organic agriculture: A comprehensive review. Environmental Health, 16(111):1-12, https://doi. org/10.1186/s12940-017-0315-4

13. Milovanović, D., Kovačević, V. (2017). Pretpostavke i značaj razvoja zadružnog sektora u Republici Srbiji. In: Radovic, V. (Edt.) Usklađivanje poslovnog prava Srbije sa pravom Evropske unije, Univerzitet u Beogradu, Pravni fakultet, Beograd, Srbija, pp. 30-63. 
14. Paraušić, V., Roljević Nikolic, S. (2020). Organic farming and sustainable development of rural areas: A case study of Serbia. In: Platania, M., Jeločnik, M., Gostin, I. (Eds.) Organic farming, eco-market and their capitalization through the entrepreneurial initiative, Alexandru Ioan Cuza University Press, Iasi, Romania, Institute of Agricultural Economics, Belgrade, Serbia, pp. 217-237.

15. Rajnović, Lj., Cico, S., Brljak, Z. (2020). Restitution of Agricultural Land in Serbia - Comparative Legal Aspects. Agricultural Economics, 67(4):1355-1366.

16. Serbia Organika (2021). Organska proizvodnja u Srbiji - 2020. Nacionalno udruženje za razvoj organske proizvodnje (Serbia Organika), Beograd, Srbija.

17. Seufert, V., Ramankutty, N., Mayerhofer, T. (2017). What is this thing called organic?: How organic farming is codified in regulations. Food Policy, 68:1020, https://doi.org/10.1016/j.foodpol.2016.12.009

18. SORS (2012). Census of Agriculture in Serbia: 2012. Statistical Office of the Republic of Serbia (SORS), Belgrade, Serbia.

19. Sredojević, Z., Kljajić, N., Arsić, S. (2015). Enabling environment and some indicators to organic farming in Serbia. In: Baskatova, T. (Edt.) Agrarian Science, Creativity, Growth, State Agrarian University Stavropol, Sequoia, Stavropol, Russia, pp. 167-170.

20. STIPS (2021). Basic information related the STIPS. Portal of Marketing Informational System, Ministry of Agriculture, Forestry and Water Management of the Republic of Serbia (MAFWM), Belgrade, Serbia, retrieved at: www.stips. minpolj.gov.rs/, $5^{\text {th }}$ January 2021.

21. The Rulebook on the production and trade of small quantities of food of plant origin, the area for performing these activities, as well as the exclusion, adjustment or deviation from the requirements of food hygiene, Official Gazette of RS (OGRS) no. 13/2020 of $14^{\text {th }}$ February 2020.

22. Willer, H., Schllater, B., Travnicek, J., Kemper, L., Lernoud, J. (2020). The world of organic agriculture: Statistics and emerging trends 2020. Research Institute of Organic Agriculture (FiBL), Frick, Switzerland, IFOAM Organic International, Bonn, Germany. 